
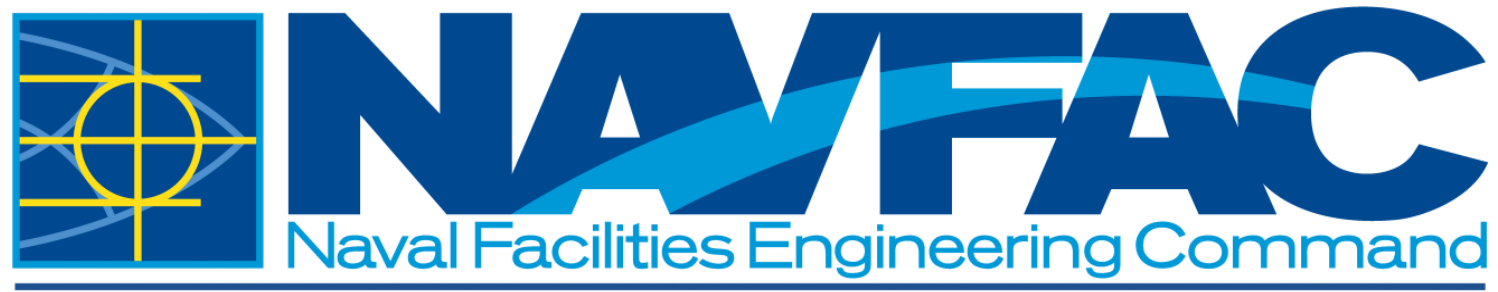

ENGINEERING AND EXPEDITIONARY WARFARE CENTER

\author{
CONTRACT REPORT \\ CR-NAVFAC-EXWC-PW-1504
}

APRIL 2015

\title{
Renewable Energy, Photovoltaic Systems Near Airfields: Electromagnetic Interference
}

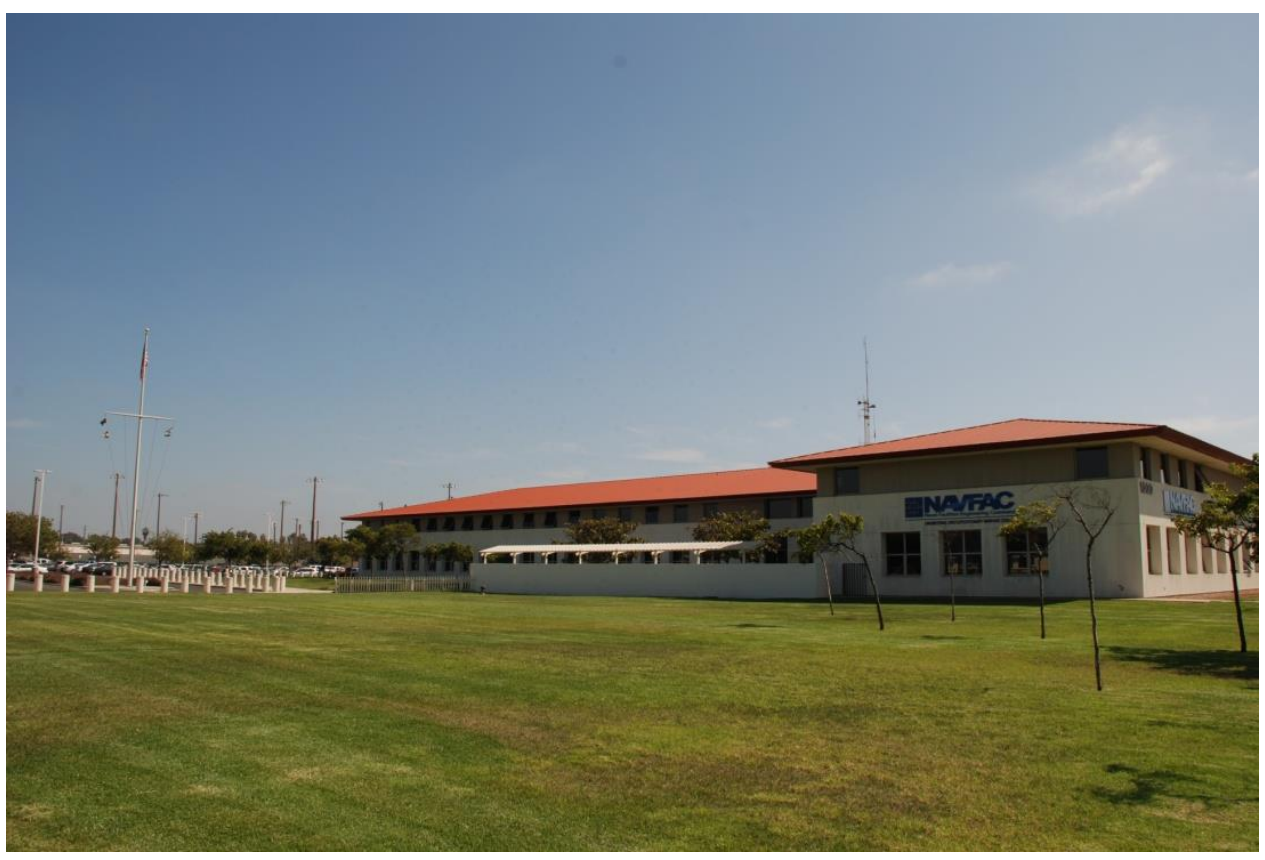

Geoff Dann, NAVFAC EXWC

Chris Deline, National Renewable Energy Laboratory (NREL) 
This page is intentionally left blank. 
Public reporting burden for this collection of information is estimated to average 1 hour per response, including the time for reviewing instructions, searching existing data sources, gathering and

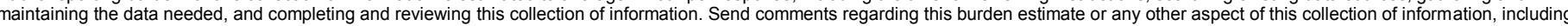

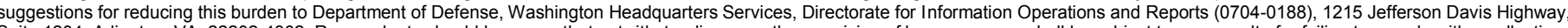

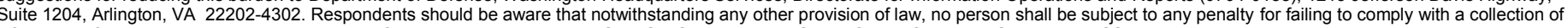
information if it does not display a currently valid OMB control number. PLEASE DO NOT RETURN YOUR FORM TO THE ABOVE ADDRESS.

\section{REPORT DATE (DD-MM-YYYY)}

$10-04-2015$

\section{TITLE AND SUBTITLE}

Renewable Energy, Photovoltaic Systems Near Airfields: Electromagnetic Interference

\section{AUTHOR(S)}

Geoff Dann, NAVFAC EXWC

Chris Deline, National Renewable Energy Laboratory (NREL)

\section{PERFORMING ORGANIZATION NAME(S) AND ADDRESS(ES)}

NAVFAC Engineering and Expeditionary Warfare Center $100023^{\text {rd }}$ Ave.

Port Hueneme, CA 93043

\section{SPONSORING / MONITORING AGENCY NAME(S) AND ADDRESS(ES)}

Commander, Naval Installations Command

716 Sicard Street SE

Suite 1000

Washington, DC 20374-5140

\section{DISTRIBUTION / AVAILABILITY STATEMENT}

Distribution approved for public release: distribution unlimited; administrative and operational use; April 2015. Other requests shall be referred to NAVFAC EXWC.

\section{SUPPLEMENTARY NOTES}

\section{ABSTRACT}

Recent increases in photovoltaic systems on Department of the Navy (DON) land and potential siting near airfields prompted this assessment of the impact of electromagnetic interference (EMI) from photovoltaic (PV) systems, on airfield electronic equipment. Existing literature is summarized, and tests to measure emissions and mitigation methods are discussed. The literature shows that the emissions from typical PV systems are low strength and unlikely to cause interference to most airfield electronic systems. With diligent procurement and siting of PV systems, including specifications for FCC Part 15 Class A compliant equipment and a 250foot setback from communication equipment, little to no EMI impact on nearby communications or telemetry equipment is anticipated.

\section{SUBJECT TERMS}

\begin{tabular}{|c|c|c|c|c|}
\hline \multicolumn{3}{|c|}{ 16. SECURITY CLASSIFICATION OF: } & $\begin{array}{l}\text { 17. LIMITATION } \\
\text { OF ABSTRACT }\end{array}$ & $\begin{array}{l}\text { 18. NUMBER } \\
\text { OF PAGES }\end{array}$ \\
\hline $\begin{array}{c}\text { a. REPORT } \\
\mathrm{U}\end{array}$ & $\begin{array}{c}\text { b. ABSTRACT } \\
U\end{array}$ & $\begin{array}{c}\text { c. THIS PAGE } \\
\text { U }\end{array}$ & UU & 13 \\
\hline
\end{tabular}

19a. NAME OF RESPONSIBLE PERSON Geoff Dann 19b. TELEPHONE NUMBER (include area code) 805-982-1366 
This page is intentionally left blank. 


\section{EXECUTIVE SUMMARY}

Recent increases in photovoltaic (PV) systems on Department of the Navy (DON) land and potential siting near airfields prompted Commander, Naval Installations Command to fund the Naval Facilities Engineering Command to evaluate the impact of electromagnetic interference (EMI) from PV systems on airfield electronic equipment. Naval Facilities Engineering and Expeditionary Warfare Center tasked Department of Energy National Renewable Energy laboratory (NREL) to conduct the assessment.

PV systems often include high-speed switching semiconductor circuits to convert the voltage produced by the PV arrays to the voltage needed by the end user. Switching circuits inherently produce electromagnetic radiation at harmonics of the switching frequency.

In this report, existing literature is summarized and tests to measure emissions and mitigation methods are discussed. The literature shows that the emissions from typical PV systems are low strength and unlikely to cause interference to most airfield electronic systems. With diligent procurement and siting of PV systems, including specifications for FCC Part 15 Class A compliant equipment and a 250 -foot setback from communication equipment, NREL anticipates little to no EMI impact on nearby communications or telemetry equipment. 
This page is intentionally left blank. 


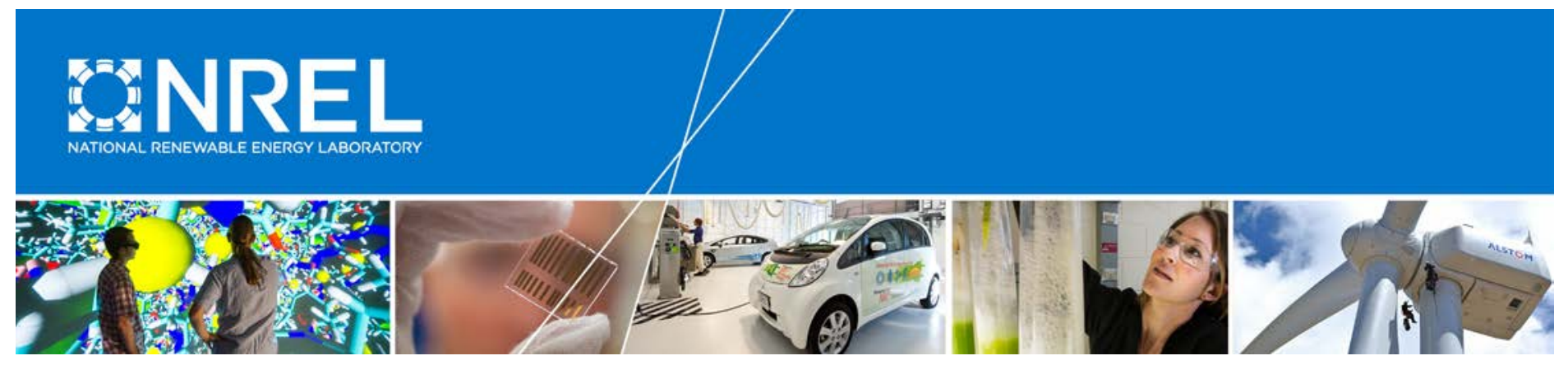

\section{Renewable Energy, Photovoltaic Systems Near Airfields: Electromagnetic Interference}

Chris Deline National Renewable Energy Laboratory

Produced under direction of Naval Facilities Engineering and Expeditionary Warfare Center by the National Renewable Energy Laboratory (NREL) under Interagency Agreement 12-1869 and Task Nos. SS12.3050 and WFHB.1006.

NREL is a national laboratory of the U.S. Department of Energy Office of Energy Efficiency \& Renewable Energy Operated by the Alliance for Sustainable Energy, LLC

This report is available at no cost from the National Renewable Energy Laboratory (NREL) at www.nrel.gov/publications.

Strategic Partnership Project Report NREL/TP-5J00-63310

April 2015

Contract No. DE-AC36-08GO28308 


\section{Renewable Energy, Photovoltaic Systems Near Airfields: Electromagnetic Interference}

Chris Deline

National Renewable Energy Laboratory

Prepared under Task Nos. SS12.3050 and WFHB.1006
NREL is a national laboratory of the U.S. Department of Energy Office of Energy Efficiency \& Renewable Energy Operated by the Alliance for Sustainable Energy, LLC

This report is available at no cost from the National Renewable Energy Laboratory (NREL) at www.nrel.gov/publications.

Strategic Partnership Project Report

NREL/TP-5J00-63310

April 2015

Contract No. DE-AC36-08GO28308
National Renewable Energy Laboratory 15013 Denver West Parkway

Golden, CO 80401

303-275-3000 • www.nrel.gov 


\section{NOTICE}

This manuscript has been authored by employees of the Alliance for Sustainable Energy, LLC ("Alliance") under Contract No. DE-AC36-08GO28308 with the U.S. Department of Energy ("DOE”).

This report was prepared as an account of work sponsored by an agency of the United States government. Neither the United States government nor any agency thereof, nor any of their employees, makes any warranty, express or implied, or assumes any legal liability or responsibility for the accuracy, completeness, or usefulness of any information, apparatus, product, or process disclosed, or represents that its use would not infringe privately owned rights. Reference herein to any specific commercial product, process, or service by trade name, trademark, manufacturer, or otherwise does not necessarily constitute or imply its endorsement, recommendation, or favoring by the United States government or any agency thereof. The views and opinions of authors expressed herein do not necessarily state or reflect those of the United States government or any agency thereof. 


\section{Contents}

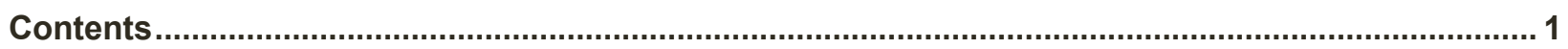

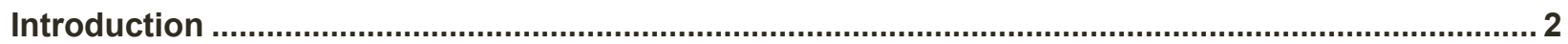

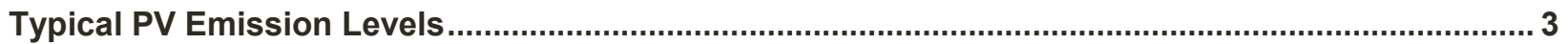

Typical Emission Spectra and Countermeasures …......................................................................... 4

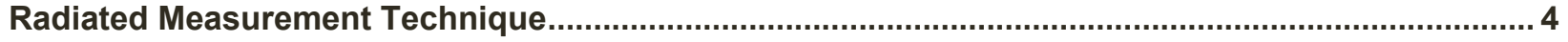

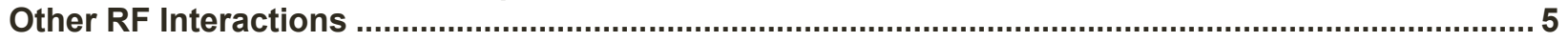

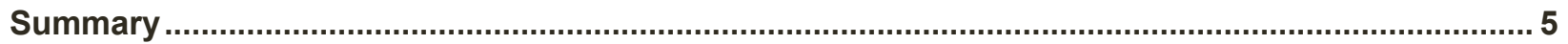

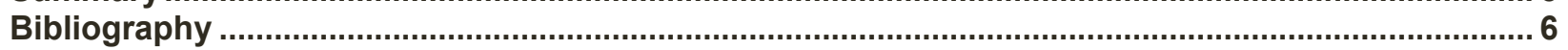

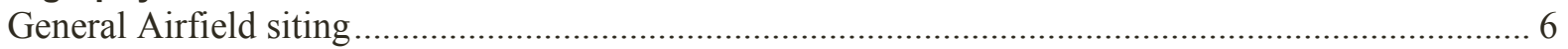

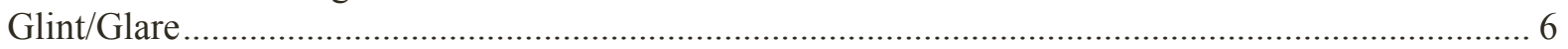

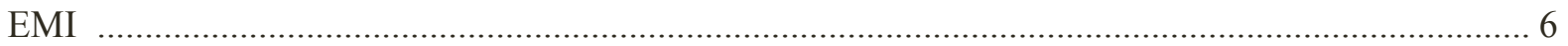




\section{Introduction}

Directives to reduce the military's carbon footprint have led to an increased interest in photovoltaic (PV) systems deployed on military installations in the U.S. Sites near airfields are proving to be suitable for the deployment of PV systems, in addition to the customary locations on buildings and in open areas. However, specific considerations must be taken when deploying PV near sensitive communications or navigation equipment that is typically found near civilian and military airfields.

Recent publications have provided guidelines for locating PV systems near civilian or military airfields. The main siting challenges relate to glint and glare that can occur from PV modules when the sun is at a high incidence angle, as well as observing keep-away zones on approach paths. Excellent summaries detailing the challenge of deploying PV near airports include the FAA's 2010 Solar Guide [FAA, 2010] and other summaries such as [Barrett, 2011] and [Kandt, 2014]. Specific guidance on glint and glare can also be found on Sandia National Laboratory's website at www.sandia.gov/glare.

This white paper addresses one aspect of PV interaction that is underserved in the literatureelectromagnetic interference (EMI). Typically, this phrase is taken to mean radiofrequency (RF) emissions, emanating from PV systems, that are impacting nearby radio receivers. This can also include any blocking or attenuation of nearby radar or communications by the PV system. Although the risk of EMI from PV systems is typically very low, it does merit evaluation, if only to improve the confidence of site owners and other stakeholders.

Several case studies have indicated that EMI from PV installations are low risk. For instance, the FAA Solar Guide states that:

"Due to their low profiles, solar PV systems typically represent little risk of interfering with radar transmissions. In addition, solar panels do not emit electromagnetic waves over distances that could interfere with radar signal transmissions, and any electrical facilities that do carry concentrated current are buried beneath the ground and away from any signal transmission."

Also, a recent Air Force Tiger Team investigation into PV near airbases found the following:

"Prior research and field investigations of electromagnetic emission (EME) from Solar PV arrays concluded that they produce extremely low frequency EME similar to electrical appliances and wiring....At a distance of 150 feet from the inverters, these fields dropped back to very low levels of $0.5 \mathrm{mG}$ or less, and in many cases to much less than background levels $(<0.2 \mathrm{mG})$.

When considering sites for a PV array in close proximity to airfield instruments, the tolerance of the equipment to EME should be considered. If of concern, the 
methodology developed by the Air Force Research Lab for the ACC study can be applied in an engineering evaluation to validate a no-impact determination."

\section{Typical PV Emission Levels}

The Federal Communications Commission CFR Title 47, Part 15 regulates RF emissions from commercial products. Compliance with Part 15 is not a requirement for large-scale power generation equipment, but many PV inverter manufacturers do qualify their residential or utilityscale equipment to this standard and it is easily validated when procuring equipment.

The FCC limits specify an upper bound on the amount of radiated emission that can be tolerated for a listed product. In practice, the amount of actual radiation from PV systems is typically so small as to be immeasurable above background RF noise. Multiple investigations into the topic were unable to detect any radiated EMI [Bonn, 1997; Piazza 2004]. This is explained by the low switching frequency of the PV inverter relative to RF frequencies; fundamental switching frequencies in the inverter are on the order of tens of $\mathrm{kHz}$, with higher-order harmonics only up to $\sim 10 \mathrm{MHz}$ [Araneo 2009]. These long-wavelength modes do not effectively couple to the outside environment, thereby limiting the strength of any radiated emission. Additionally, proper enclosure grounding, filtering, and circuit layout further reduce conducted and radiated emission.

To illustrate the relative emissions for FCC-compliant equipment, the following plot shows field strength vs. distance for a transmitting cell phone, and the maximum output of a FCC-compliant inverter. Comparing the field strength of both devices, the maximum expected field strength for a compliant inverter at a distance of 100 feet is comparable to the field strength of a cell phone a mile away. This is likely to be indistinguishable from background noise.

\footnotetext{
${ }^{1}$ Extracted from the unpublished "Solar PV Compatibility Project Tiger Team Final Report," developed by a Tiger Team assembled by the Air Force Encroachment Management Working Group. NREL received a copy from Naval Facilities Engineering Command, Atlantic.
} 


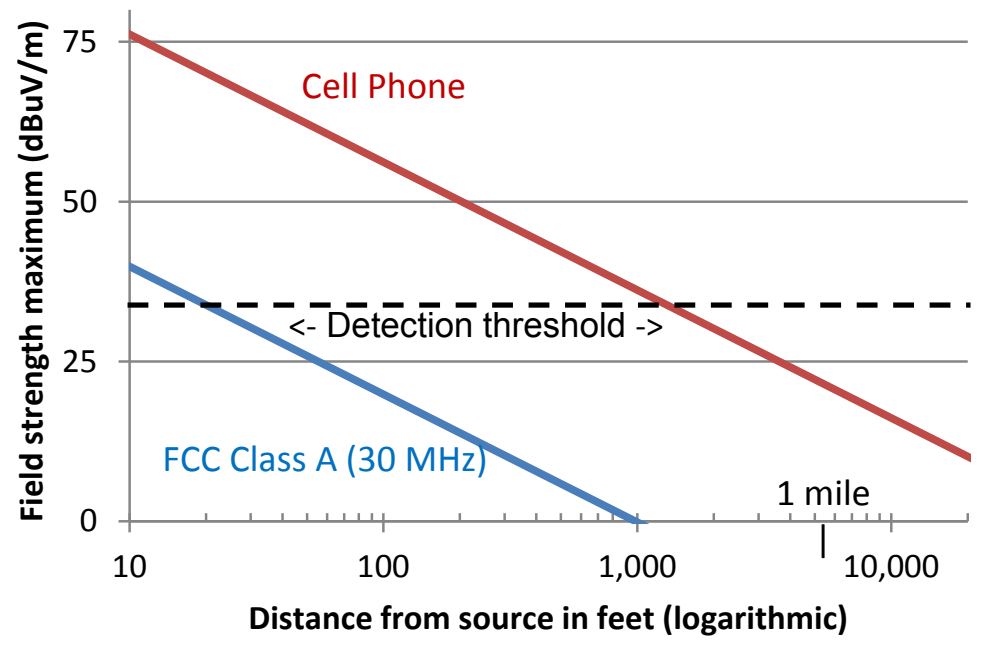

Figure 1: Measured transmit signal power (logarithmic $\mathrm{dBuV} / \mathrm{m}$ ) for a typical cell phone (red) and maximum allowed FCC class 'A' emission at $30 \mathrm{MHz}$.

Other pieces of PV systems equipment, such as step-up transformers, are not a source of electromagnetic interference because of their low-frequency $(60 \mathrm{~Hz})$ operation.

\section{Typical Emission Spectra and Countermeasures}

Compliance with FCC Part 15 radiated specification does not guarantee a lack of interference. Sensitive receivers operating below $30 \mathrm{MHz}$ may be affected, e.g., AM radios. In particular, compatibility with nearby aeronautic navigation aids such as Nondirectional Radio Beacons (NDB) or VHF omnidirectional radio range (VOR) should be assessed, per the more restrictive siting requirements of (FAA, 1986). Plots of internal conducted emissions for commercial PV inverters (e.g., Araneo, 2009) show that internal frequencies attenuate rapidly at frequencies above $300 \mathrm{kHz}$. This suggests that any interaction between PV systems and nearby communications equipment is only likely to occur at frequencies below $1 \mathrm{MHz}$, if at all.

In the unlikely event of interactions with nearby receivers or transmitters in these low frequency ranges, options are available to address the interference. For instance, while commercial inverters are equipped with inductor-capacitor (LC) filters that are optimized for system efficiency and cost, aftermarket LC filters can be installed to attenuate RF emissions at specific frequencies causing undesired interaction. Additional countermeasures may include enhanced equipment grounding of the PV modules, or specifying an inverter that solidly grounds negative PV conductors rather than leaving PV conductors ungrounded. Specification of FCC class 'A' compliant equipment will provide the best insurance against RF interference.

\section{Radiated Measurement Technique}

To conduct field measurements of radiated emission, a wide-band spectrum analyzer with sensitivity down to $150 \mathrm{kHz}$ is required, along with an appropriate antenna. At high frequencies $(>1 \mathrm{GHz}$ ), a wideband antenna such as a biconical or log-periodic antenna has good response. At frequencies below $30 \mathrm{MHz}$, the magnetic component of radiated emissions is typically 
monitored using a current clamp or loop magnetic antenna. The spectral signature of radiated emissions should be assessed both with the inverter turned off (background signature) and while operating at full power to determine the inverter's radiated emissions. A broadband increase in the level of RF emissions would indicate the presence of radiated emission from the inverter.

\section{Other RF Interactions}

At frequencies greater than $1 \mathrm{GHz}$, the impact of PV systems on communications is limited to the physical obstruction and reflection of these signals. This is particularly the case for collimated line-of-sight signals such as laser or infrared communications. PV systems are similar to other built structures such as buildings or sheds in that they are constructed of metal and glass, and they are non-transmitting. Similar consideration due to reflection and multipath should be given to PV systems, as well. In the FAA Solar Guide, several airport case studies indicate that setbacks of 250-500 feet were maintained between new PV systems and existing radar equipment. These setback values were sufficient to preclude impacts to the communication equipment. Similar modest exclusion zones should be considered for other critical telemetry or navigation equipment at civilian or military airfields.

\section{Summary}

Photovoltaic inverters are inherently low-frequency devices that are not prone to radiating EMI. No interference is expected above $1 \mathrm{MHz}$ because of the inverters' low-frequency operation. In addition, interaction at lower frequencies $(100 \mathrm{kHz}-1 \mathrm{MHz})$ is also very low risk because of the poor coupling of these extremely long wavelengths to free space, limiting propagation of the signal. In some cases where PV systems were deployed near existing radar equipment, a setback distance of 250-500 feet was implemented to minimize the physical blocking or reflection of the radar signals by the PV system. A similar 250-foot setback near any other critical communication equipment could be considered in order to attenuate any low-frequency emitted radiation that may be produced by the PV system. Siting near VOR equipment should reference FAA order 6820.10 .

With diligent procurement and siting of PV systems, including specifications for FCC Part 15 Class A compliant equipment and a 250 -foot setback from communication equipment, NREL anticipates little to no EMI impact on nearby communications or telemetry equipment. 


\section{Bibliography}

\section{General Airfield siting}

Air Force Civil Engineering Center, Planning and Integration Directorate, Regional Planning Development Branch (2014). Solar PV Compatibility Project Tiger Team, Final report.

Barrett, S. B., and P.M. DeVita (2011) Investigating Safety Impacts of Energy Technologies on Airports and Aviation. Vol. 28. Transportation Research Board. http://onlinepubs.trb.org/onlinepubs/acrp/acrp_syn_028.pdf

FAA Order 6820.10 (1986) VOR,VOR/DME and VORTAC Siting Criteria. http://www.faa.gov/documentLibrary/media/Order/6820.10.pdf

FAA Technical Guidance for Evaluating Selected Solar Technologies on Airports, (2010) http://www.faa.gov/airports/environmental/policy_guidance/media/airport_solar_guide_print.pdf

Kandt A., Romero R., (2014) "Siting Solar Photovoltaics at airports", Solar 2014 Conference Proceedings, San Francisco, CA July 2014, NREL/CP-7A40-62304.

http://www.nrel.gov/docs/fy14osti/62304.pdf

\section{Glint/Glare}

Ho, C.K., C.M. Ghanbari, and R.B. Diver (2011), Methodology to Assess Potential Glint and Glare Hazards From Concentrating Solar Power Plants: Analytical Models and Experimental Validation, Journal of Solar Energy Engineering-Transactions of the ASME, 133(3).

Ho, C.K. and C.A. Sims,(2012), Solar Glare Hazard Analysis Tool (SGHAT) User's Manual v. 1.0, Sandia National Laboratories, SAND2012-10761P, Albuquerque, NM., sandia.gov/glare.

\section{EMI}

Araneo, R., S. Lammens, M. Grossi, and S. Bertone (2009). EMC Issues in High-Power GridConnected Photovoltaic Plants, IEEE Transactions on Electromagnetic Compatibility, 51(3), 639-648.

Bonn, R. (1997), FCC Part 15 Rules and PV Systems, Sandia Technical Note, SAND97-1043.

Di Piazza, M.C., G. Tine, C. Serporta, and G. Vitale (2004) Electromagnetic Compatibility Characterization of the DC Side in a Low Power Photovoltaic Plant," in Proc. IEEE Int. Conf. Ind. Tech., 672-677.

Hong, S., and M. Zuercher-Martinson (2013). Harmonics and Noise in Photovoltaic (PV) Inverter and the Mitigation Strategies. Solectria Renewables White Paper, accessed 9/2014 http://www.solectria.com//site/assets/files/1482/solectria harmonics noise pv inverters white paper.pdf 